\title{
Pelatihan Penulisan Karya Tulis Ilmiah Bagian Abstrak dan Pendahuluan Model Induktif Partisipatif pada Guru SMA/SMK/MA dan Dosen Bahasa di Lubuk Linggau dalam Peningkatan Profesionalitas
}

\author{
Arono ${ }^{1)}$, Safnil Arsyad ${ }^{2)}$ \\ ${ }^{1,2)}$ Universitas Bengkulu \\ arono@unib.ac.id
}

\begin{abstract}
ABSTRAK : Tidak semua guru dan dosen memahami gaya penulsan hasil penelitian atau karya ilmiah yang baik, baik diterbitkan dalam prosiding maupun dalam jurnal khususnya bagian abstrak dan pendahuluan. Tujuan pengabdian ini untuk meningkatkan kualitas guru profesional melalui model pelatihan induktif partisipatif dalam penulisan karya tulis ilmiah bagian abstrak dan pendahuluan. Model pelatihan induktif partisipatif penulisan karya tulis ilmiah jurnal hasil penelitian dalam meningkatkan kualitas profesional guru dan dosen bahasa di Lubuk Linggau bermanfaat bagi pengembangan profesional guru dan dosen dalam penulisan karya ilmiah yang bermutu, mendapatkan pengetahuan dan wawasan yang luas terhadap perkembangan ilmu dan jurnal ilmiah baik lokal maupun nasional, meningkatkan intensitas program dalam wadah prfoesionalitas guru melalui Musyawarah Guru Mata Pelajaran (MGMP), dan mampu berkompetensi dalam konfererensi atau seminar baik nasional maupun internasional, serta publikasi seperti Seminar Nasional MLI Cabang Bengkulu, JOALL, Wacana, Diksa, Triadik, dan Analisis Jurnal Penelitian Pendidikan.
\end{abstract}

Kata Kunci: karya tulis ilmiah, guru bahasa, profesionalitas

\begin{abstract}
Not all teachers and lecturers understand the penulant style of research results or good scientific work, both published in proceedings and in journals, especially the abstract and preliminary sections. The purpose of this service is to improve the quality of professional teachers through participatory inductive training models in abstract and preliminary scientific writing. The participatory inductive training model of scientific journal writing research results in improving the professional quality of language teachers and lecturers in Lubuk Linggau is useful for the professional development of teachers and lecturers in writing scientific quality works, gaining extensive knowledge and insight into the development of local science and scientific journals and nationally, increasing program intensity in teacher professionalism through Subject Teachers' Consultation (MGMP), and be able to compete in conferences or seminars both nationally and internationally, as well as publications such as the MLI National Seminar Bengkulu Branch, JOALL, Discourse, Diksa, Triadik, and Analysis: Journal of Educational Research.
\end{abstract}

Keywords : scientific papers, language teachers, professionalism

\section{PENDAHULUAN}

Salah satu komponen portofolio sertifikasi guru dari sepuluh komponen yang harus dimiliki guru, yaitu karya pengembangan profesi dan keikutsertaan dalam forum ilmiah (Permendiknas, 2007). Hal itu diperkuat juga Leutuan (2010) bahwa ada empat komponen belum sepenuhnya dapat diakses dan dikuasai oleh setiap guru, yaitu pendidikan dan pelatihan, keikutsertaan dalam forum ilmiah, prestasi akademik, dan 
karya pengembangan profesi. Frekuensi kegiatan pelatihan dan pendidikan, forum ilmiah, dan momen-momen lomba akademik relatif masih terbatas. Begitu juga budaya menulis, budaya meneliti dan berinovasi kurang sepenuhnya berkembang di kalangan guru. Semua ini tentu akan menyebabkan kesulitan tersendiri bagi para guru untuk meraih poin dari komponen-komponen tersebut.

Undang-Undang Republik Indonesia nomor 14 tahun 2005 tentang Guru dan Dosen, mengisyaratkan bahwa guru adalah pendidik profesional dengan tugas utama mendidik, mengajar, membimbing, mengarahkan, melatih, menilai, dan mengevaluasi peserta didik pada pendidikan anak usia dini jalur pendidikan formal, pendidikan dasar, dan pendidikan menengah. Profesionalisme dalam pendidikan perlu dimaknai bahwa guru haruslah orang yang memiliki instink sebagai pendidik, mengerti dan memahami peserta didik. Guru harus menguasai secara mendalam minimal satu bidang keilmuan. Guru harus memiliki sikap integritas profesional. Kedudukan guru sebagai tenaga profesional sebagaimana dimaksud dalam Pasal 2 ayat (1) berfungsi untuk meningkatkan martabat dan peran guru sebagai agen pembelajaran berfungsi untuk meningkatkan mutu pendidikan nasional. Yang dimaksud dengan guru sebagai agen pembelajaran (learning agent) adalah peran guru antara lain sebagai fasilitator, motivator, pemacu, perekayasa pembelajaran, dan pemberi inspirasi belajar bagi peserta didik.

Kompetensi guru sebagaimana yang dimaksud dalam Pasal 8 Undang-Undang Republik Indonesia nomor 14 tahun 2005 meliputi kompetensi pedagogik, kompetensi kepribadian, kompetensi sosial, dan kompetensi profesional yang diperoleh melalui pendidikan profesi. Kompetensi profesional merupakan hal yang utama penunjang profesi seorang guru yang sudah bersertifikasi. Adapun kompetensi profesional merupakan kemampuan guru dalam menguasai pengetahuan bidang ilmu, teknologi, dan/atau seni yang sekurang-kurang meliputi penguasaan (1) materi pelajaran secara luas dan mendalam sesuai standar isi program satuan pendidikan, mata pelajaran, dan/atau kelompok mata pelajaran yang diampunya, dan (2) konsep-konsep dan metode disiplin keilmuan, teknologi, atau seni yang relevan yang secara konseptual menaungi atau koheren dengan program satuan pendidikan, mata pelajaran, dan/atau kelompok mata pelajaran yang diampu. Namun, dalam kenyataannya penunjang profesional guru masih terkendala pada kenaikan pangkatnya, guru terhalang Permenpan No. 84/1993 yang mewajibkan guru untuk naik pangkat dari IVa ke atas dipersyaratkan mengembangkan keprofesionalannya deangan membuat karya inovatif berupa karya ilmiah dengan bobot angka kredit 12 .

Penulisan karya ilmiah dapat dilakukan dalam laporan penelitian atau ide ilmiah yang dapat dipublikasikan dalam sebuah jurnal atau prosiding yang bereputasi nasional ataupun internasional atau yang ber-ISBN/ber-ISSN. Penulisan karya ilmiah ini kadang memerlukan waktu, tenaga, pikiran, dan biaya yang cukup tinggi. Hal itu memerlukan proses yang tidak serta-merta bisa terselesaikan dalam kurun waktu yang relatif pendek 
sehingga dalam penulisannya perlu bertahap dan berkesinambungan. Untuk itu, dalam kesempatan ini penulis memfokuskan pada pelatihan karya tulis ilmiah bagian abstrak dan pendahuluan saja. Kondisi demikian kurang memungkinkan guru dalam melaksanakannya sehingga peneliti memerlukan andil dalam menyikapi permasalahan ini dalam bentuk pelatihan karya ilmiah dengan model induktif partisifasi dalam peningkatan profesional guru SMA/MA/SMK dan dsoen.

Guru yang ada yang ada di Kabupaten Musi Rawas Kota Lubuk Linggau khususnya bidang studi Bahasa Inggris dan Bahasa Indonesia hendaknya menjadi kiblat bagi kualitas guru yang ada di Lubuk Linggau. Namun, kenyataannya hal itu masih kurang menjadi acuan dalam kualitas karya ilmiahnya khususnya. Guru bahasa Inggris dan guru bahasa Indonesia begitu juga dengan dosennya masih minim dalam penulisan dan publikasi terhadap karya ilmiah padahal jumlah guru yang sudah bersertifikasi sudah memungkinkan untuk pengembangkan karya ilmiah dalam wadah Musyawarah Guru Mata Pelajaran (MGMP), yaitu hampir rata-rata setiap sekolah sudah memiliki lima hingga tujuh orang bahasa Inggris. Kurangnya optimalisasi kegiatan Musyawarah Guru Mata Pelajaran (MGMP) sehingga pengembangan dan kreatifitas guru dalam penulisan karya ilmiah juga menemui hambatan. Untuk itu, pelatihan ini memfasilitasi guru dalam wadah Musyawarah Guru Mata Pelajaran (MGMP) untuk meningkatkan aktivitas dan program kerja dalam organisasinya yang kontinu. Hal itu diharapakan dengan pelatihan ini ditemukan permasalahan dalam penulisan karya ilmiah, permasalahan pembelajaran, berbagai pengembangan topik atau ide penulisan, hingga hingga pada draf publikasi karya ilmiah.

\section{Gaya Retorika Abstrak dan Pendahuluan}

Abstrak merupakan bagian penting dalam artikel jurnal karena akan menentukan keinginan pembaca akan terus meneruskan bacaan artikel tersebut atau tidak. Selain itu, asbtrak merupakan gambaran terhadap isi artikel yang ditulis. Abstrak berfungsi sebagai miniatur artikel yang berisikan topik, metode, dan temuan penelitian; alat menyeleksi artikel yang akan dibaca selanjutnya; preveiuw artikel secara utuh; mengindeks karyakarya ilmiah yang dipublikasikan bagi penulis (Huckin dalam Arsyad, 2014).

Penulisan abstrak dari setiap jurnal atau negara mengalami perbedaan tergantung dengan pengguna dan kebutuhan tulisan. Namun, secara umum tahapan dalam penulisan abtrak, yaitu latar belakang, tujuan penelitian, metode penelitian, temuan penelitian, dan kesimpulan/saran/implikasi (adaptasi dari Swales dan Freak; Bathia; dalam Arsyad, 2014:53-54). Tahap inilah yang akan menjadi acuan pengabdian dalam mengevaluasi draf abstrak awal penulis. Berdasarkan hal itu, penulis akan menganalisis dan menabulasikan hasil draf abstrak sementara setelah itu diadakan pelatihan.

Pendahuluan mengandung nilai argumentatif dan persuasif karena penulis harus meyakinkan pembaca agar menerima bahwa kegiatan penelitian yang telah dilakukan menarik dan penting (Hunston dalam Safnil dan Arono, 2016:8). Hal itu menjadikan bagian pendahuluan merupakan penulisan yang lebih sulit dibandingkan dengan bagian 
yang lain (Swales dalam Safnil dan Arono, 2016:8). Adapun gaya retorika yang akan diterapkan dalam pelatihan ini, yaitu pola CARS, tetapi telah direvisi menjadi PJP (Problem Justifying Project). Adapun pola PJP (Safnil dan Arono, 2016:12-20), yaitu menyiapkan pengetahuan pembaca (mendefinisikan istilah kunci, menjelaskan sejarah bidang penelitian, mendefiniskan letak geografis peneilitian, menyatakan klaim umum), memperkenalkan bidang penelitian (memperkenalkan topik penelitian, mengidentifikasi masalah peenlitian, mengacu kepada kebijakan dan perturan pemerintah, merujuk pada literature), menjastifikasi kegiatan penelitian (mengidentifikasi kesenjangan dalam penelitian terdahulu, menyatakan bahwa topik tersebut belum pernah diteliti, menyatakan tertarik meneliti topik tersebut), dan memperkenalkan kegiatan p[enelitian (menyatakan tujuan penelitian, masalah penelitian, menjeaskan fitur khusus penelitian, menyatakan manfaaat penelitian, mengumumkan hasil penting penelitian, menyatakan hipotesis penelitian, menyatakan solusi terhadap masalah penelitian).

\section{Model Pelatihan Induktif Partisipatif Penulisan Karya Ilmiah}

Undang-Undang Nomor 14 Tahun 2005 tentang Guru dan Dosen merupakan sebuah perjuangan sekaligus komitmen untuk meningakatkan kualitas guru yaitu kualifikasi akademik dan kompetensi profesi pendidik sebagai agen pembelajaran. Kualifikasi akademik diperoleh melalui pendidikan tinggi program sarjana (S1) atau D4. Kompetensi profesi pendidik meliputi kompetensi pedagogik, kompetensi kepribadian, kompetensi profesional dan kompetensi sosial. Dengan sertifikat profesi, yang diperoleh setelah melalui uji sertifikasi lewat penilaian portofolio (rekaman kinerja) guru, seorang guru berhak mendapat tunjangan profesi sebesar 1 bulan gaji pokok. Intinya, Undang-Undang Guru dan Dosen adalah upaya meningkatkan kualitas kompetensi guru seiring dengan peningkatan kesejahteraan mereka.

Supriadi (1999) mengatakan bahwa bahwa profesionalisme menunjuk pada derajat penampilan seseorang sebagai profesional atau penampilan suatu pekerjaan sebagai profesi, ada yang profesionalismenya tinggi, sedang, dan rendah. Profesionalisme juga mengacu kepada sikap dan komitmen anggota profesi untuk bekerja berdasarkan standar yang tinggi dan kode etik profesi. Dengan demikian profesionalisme merupakan performance quality dan sekaligus sebagai tuntutan perilaku profesional dalam melaksanakan tugasnya. Konsekuensinya guru sebagai profesional dituntut untuk bisa bekerja dalam koridor profesionalisme. Sebagai pekerja profesi, guru sharus menjunjung profesionalisme. Pengertian umum profesionalisme menunjukkan kerja keras secara terlatih tanpa adalanya persyaratan tertentu. Pemahaman secara scientific profesionalisme menunjuk pada ide, aliran, atau pendapat bahwa suatu profesi harus dilksanakan oleh profesional denganmengacu kepada profesionalisme.

Profesi menunjuk pada suatu pekerjaan atau jabatan yang menuntut keahlian , tanggung jawab, dan kesetiaan terhadap profesi. Suatu profesi secara teori tidak bisa dilakukan oleh sembarang orang yang tidak dilatih atau disiapkan untuk itu. (Supriadi: 1999). Jadi, profesi bukanlah sembarang pekerjaan, tetapi pekerjaan yang berlandaskan 
pada keahlian. Keahlian tersebut diperoleh melalui suatu pendidikan dan pelatihan melalui suatu lembaga yang telah mendapat otoritas. Oleh karena itu, guru yang sudah tersertifikasi dituntut meningkatkan kualitas profesionalitasnya, salah satunya dengan menulis karya tulis ilmiah dan pelatihan atau kegiatan ilmiah lainnya.

Salah satu bentuk karya tulis ilmiah adalah artikel. Namun, dalam model pelatihan karya tulis ilmiah ini yang akan dikembangkan, yaitu karya tulis ilmiah hasil penelitian. Adapun yang dimaksud dengan artikel adalah karangan ilmiah faktual secara lengkap yang menyampaikan gagasan/permasalahan agar dapat meyakinkan, mendidik, dan menghibur untuk dipublikasikan (melalui koran, majalah, buletin, jurnal, dsb.). Artikel dari hasil penelitian ini peneliti sebut dengan artikel jurnal. Artikel jurnal adalah karangan ilmiah dalam bidang ilmu tertentu yang diterbitkan dalam sebuah jurnal yang khusus menerbitkan bidang kajian ilmu tersebut. Adapun kategori artikel jurnal, yaitu artikel hasil analisis suatu topik, tanpa mengaitkan penelitian dan artikel yang berisi kajian hasil penelitian.

Pelatihan sebagai sebuah konsep program yang bertujuan meningkatkan pengetahuan dan keterampilan seseorang (sasaran didik), berkembang sangat pesat dan modern (Kamil, 2003). Salah satu konsep mengapa model pelatihan dibangun adalah sangat bergantung pada kondisi itu (warga belajar, sasaran didik dan pelatih/tutor). Hal tersebut sangat beralasan karena kebutuhan dan tujuan pelatihan dapat tercapai apabila warga belajar, tutor saling memahami, menghargai, pengertian dan saling membelajarkan satu dengan lainny (Sudjana, 1993:12). Suatu model pelatihan dianggap efektif manakala mampu dilandasi kurikulum, pendekatan dan strategi yang sesuai dengan kebutuhan belajar sasaran didik dan permasalahan-permasalahan yang terjadi di tengah-tengah nya. Untuk itu diperlukan persyaratan khusus dalam membangun sebuah model pelatihan yang efektif dan efesien. Persyaratan tersebut diantaranya adalah kebutuhan belajar peserta pelatihan (sasaran didik, warga belajar dll.) istilah tersebut dalam dunia pendidikan luar sekolah dikenal dengan TNA (Training Needs Assessment), SMA (Subject Matter Analysis) dan ATD (Approaches to Training and Development) (Rossett and Arwady, 1987). Untuk itu, model pelatihan yang akan dilakukan ini berdasarkan pada kebutuhan peserta pelatihan atau pelajar, yaitu model induktif partisipatif.

Murdick dan Ross (dalam Amirin, 2001:70) mendefinisikan istilah model merupakan abstraksi realitas, suatu penghampiran kenyataan. Model tidak bisa menceritakan perincian atau detail kenyataan tersebut, melainkan hanya porsi atau bagian-bagian tertentu yang penting saja. Hal yang sama juga dikatakan oleh Awadr (dalam Amirin, 2001: 70) model itu merupakan pencerminan, penggambaran sistem yang nyata atau direncanakan. Dalam kaitanya dengan model pelatihan Atmodiwirio (2002: 56) mendefinisikan desain (rancang bangun) adalah proses perencanaan yang menggambarkan urutan kegiatan (sitematika) mengenai suatu program. Berdasarkan penjelasan tersebut, model pelatihan merupakan gambaran secara menyeluruh tentang 
langkah-langkah apa saja yang harus dilakukan dalam siklusnya terbagi ke dalam tiga tahapan, yaitu tahap perencanaan, tahap pelaksanaan, dan tahap evaluasi.

Model induktif menekankan pada usaha yang dilakukan dari pihak yang terdekat, langsung, dan bagian-bagian ke arah pihak yang luas, dan menyeluruh (Kamil, 2003). Oleh karena itu, melalui pendekatan ini diusahakan secara langsung pada kemampuan yang telah dimiliki setiap sasaran didik (pelatihan), kemudian membandingkannya dengan kemampuan yang diharapkan atau harus dimiliki sesuai dengan tuntutan yang datang kepada dirinya. Model ini digunakan untuk mengidentifikasi jenis kebutuhan belajar yang bersifat kebutuhan terasa (felt needs) atau kebutuhan belajar dalam pelatihan yang dirasakan langsung oleh peserta pelatihan. Pelaksanaan identifikasinya pun harus dilakukan secara langsung kepada peserta pelatihan itu sendiri. Untuk itu, model pendekatan ini digunakan bagi peserta pelatihan yang sudah ada (hadir menjadi peserta pelatihan).

Model pelatihan induktif partisipatif menekankan pada proses pembelajaran, kegiatan belajar dalam pelatihan dibangun atas dasar partisipasi aktif (keikutsertaan) peserta pelatihan dalam semua aspek kegiatan pelatihan, mulai dari kegiatan merencanakan, melaksanakan, sampai pada tahap menilai kegiatan pembelajaran dalam pelatihan. Upaya yang dilakukan pelatih pada prinsipnya lebih ditekankan pada motivasi dan melibatkan kegiatan peserta (Kamil, 2003). Adapun model pelatihan induktif partisipatif, yaitu dapat dilakukan dengan beberapa tahapan: 1) Teknik dalam tahap pembinaan keakraban: teknik diad, teknik pembentukan kelompok kecil, teknik pembinaan belajar berkelompok, teknik bujur sangkar terpecah (brken square), 2) Teknik yang dipergunakan pada tahap identifikasi : curah pendapat, dan wawancara, 3) Teknik dalam tahap perumusan tujuan : teknik Delphi dan diskusi kelompok (round table discussion), 4) Teknik pada tahap penyusunan program: teknik pemilihan cepat (Q-short technique) dan teknik perancangan program, 5) Teknik yang dapat dipergunakan dalam proses pelatihan: simulasi, studi kasus, cerita pemula diskusi (discussion starter story), buzz group, pemecahan masalah kritis, forum, role play, magang, kunjungan lapangan, dll, 6) Teknik yang dapat dipergunakan dalam penilaian proses pelatihan, hasil dan pengaruh kegiatan: respon terinci, dan pengajuan pendapat tertulis. Model tersebut dapat dilihat pada gambar 1. 


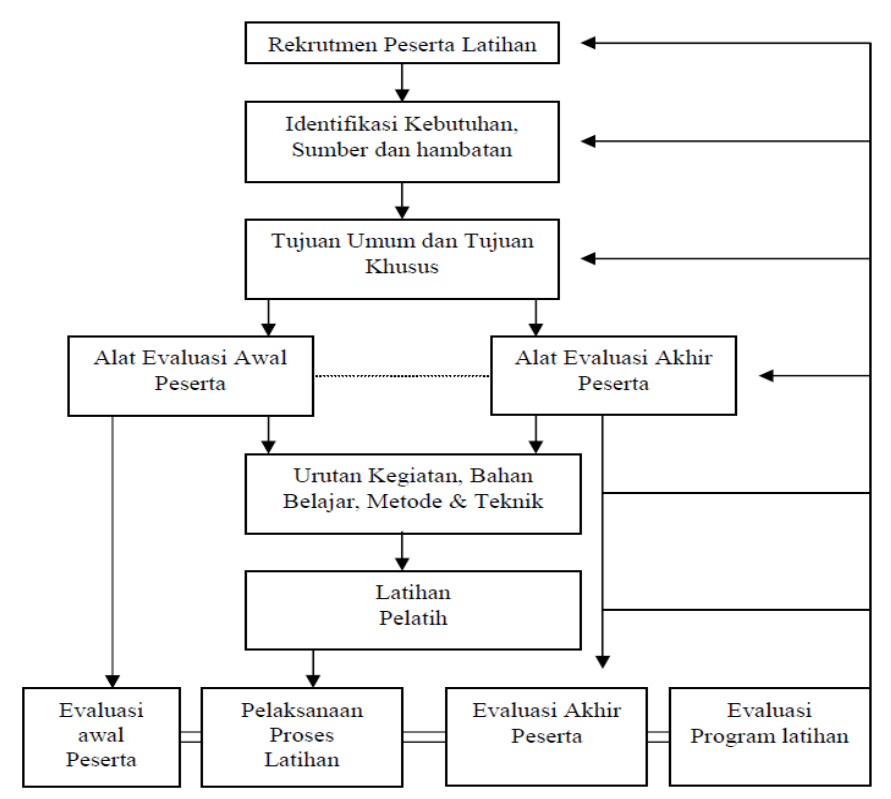

Gambar 1. Model Pelatihan Induktif Partisipatif Penulisan Karya Ilmiah

\section{PERMASALAHAN}

Profesionalitas guru yang sudah bersertifikat pendidik dalam pengembangan profesinya masih kurang pada penulisan karya ilmiah dan mengikuti pelatihan dalam hal pengembangan profesinya. Untuk itu, melalui pengaabdian ini peneliti akan melakukan pelatihan sekaligus melaksanakan publikasi karya ilmiah bagi guru-guru yang mengikuti pelatihan karya ilmiah tersebut. Berdasarkan hal itu, rumusan masalah dalam penelitian pengabdian ini, yaitu bagaimana meningkatkan kualitas profesionalitas guru yang bersertifikasi melalui model pelatihan penulisan karya tulis ilmiah bagian abstrak dan pendahuluan. Untuk menjawab hal tersebut, peneliti akan melakukan analisis kebutuhan secara empiris mengenai permasalahan guru dalam penulisan karya tulis ilmiah khususnya guru bahasa SMA/MA/SMK Kota Lubuk Linggau, melakukan pelatihan karya tulis ilmiah dengan menentukan berbagai prumusan atau permasalahan penelitian yang telah guru-guru miliki atau lakukan, memberikan berbagai pelatihan pengembangan penulisan karya tulis ilmiah/artikel pada jurnal, yaitu pengembangan ide, sistematika penulisan, kiat-kiat publikasi artikel hasil penelitian di jurnal, dan pembimbingan hasil penelitian sampai pada publikasi jurnal. Berdasarkan pelatihan tersebut akan ditemukan berbagai permsalahan dan pemecahan dalam pelatihan dan penulisan karya tulis ilmiah yang dilakukan oleh guru hingga mampu menulis draf abstrak dan pendahuluan karya tulis ilmiah. 


\section{METODE PELAKSANAAN}

Model pelatihan induktif partisipatif mampu meningkatan kualitas atau mutu tulisan guru dalam menulis karya tulis ilmiah. Model pelatihan induktif partisipatif inilah yang dijadikan metode dalam pengembangan pengabdian nantinya. Beberapa hasil penelitian dan pengabdian masyarakat dalam hal pelatihan dapat meningkatkan kualitas peserta pelatihan. Hal itu dapat dilihat berdasarkan hasil penelitian BP-PLSP REG III (2004) menunjukkan bahwa model pelatihan pamong pelajar mampu meningkatkan kemampuan menulis karya ilmiah kepada peserta pelatihannya. Kompetensi pengembangan profesi khususnya kemampuan menyusun/menulis karya tulis/ilmiah diperoleh rata-rata skor di bawah nilai 4. Dari data tersebut maka pelatihan diarahkan pada peningkatan kemampuan menyusun/menulis karya tulis/ilmiah dengan materi pokok, (1) perumusan masalah, (2) kaidah penulisan karya ilmiah/tulis, (3) metodologi penelitian, (4) analisis data, (5) teknik presentasi dan (6) praktik penyusunan karya ilmiah serta materi-materi penunjang untuk mendukung peningkatan kompetensi personal dan kompetensi budaya. Pelatihan dilaksanakan selama lima hari dengan pendekatan andragogik, menekankan pada praktek kerja, pelibatan unsur pergurutan tinggi dan praktisi serta pamong belajar senior.

\section{PELAKSANAAN}

Pelatihan model induktif partisipatif dilakukan setelah adanya penemuan beberapa permasalahan dalam penulisan karya ilmiah bagi guru. Hal tersebut dilakukan melalui angket dan wawancara secara online melalui media sosial whatshapp. Adapun hasil angket yang diberikan kepada guru dan dosen mengenai beberapa kesulitan dalam penulisan artikel jurnal, yaitu guru berpendapat dari 32 peserta menganggap bagian pendahuluan dan pembahasan mengalami kesulitan dominan dalam mengemukakan idenya dan ketidaktahuan retorikan penulisannya. Rinciannya yaitu, pendahuluan (40\%), pembahasan (25\%), hasil (15\%), metodologi (10\%), abstrak (5\%), dan penutup $(5 \%)$. Berdasrkan permasalahan ini, tim pengabdian merumuskan penulisan pada fokus pendahuluan dan bagian abstrak dalam artikel jurnal penelitian.

Adapun model pelatihan induktif partisipatif, yaitu dapat dilakukan dengan beberapa tahapan:

1. Teknik dalam Tahap Pembinaan Keakraban

Teknik ini digunakan pelatih dalam mencairkan suasana dan suasana lebih akrab. Hal itu dilakukan pelatih dengan memperkenalkan diri begitu juga dengan pesertanya. Selain itu, pelatih juga memberikan informasi dan gambaran umum berbagai permasalalahn dalam penulisan karya ilmiah, serta pengalamanpengalaman yang baik suka maupun duka dalam menulis karya ilmiah juga mempublikasikan tulisan itu. Saat itu juga beberapa peserta pelatihan diminta menceritakan pengalamannya. Umumnya peserta mengalami kesulitan dalam menuangkan ide dan mempublikasikan tulisan karya ilmiahnya dalam bentuk 
jurnal atau prosiding. Hal itu karena terbatasnya wadah publikasi dan kegiatan seminar yang dilakukan di daerahnya.

2. Teknik yang Dipergunakan pada Tahap Identifikasi

Teknik ini digunakan oleh pelatih dalam menggali informasi berbagai permasalahan peserta terhadap pengalaman yang telah dilakukan dalam penulisan karya ilmiah. Pengalaman penulis peserta tidak terlepas dari pengalaman peserta dalam melakukan aktivitas belajar dan mengajar di kelas. Lamanya pengalaman kadangkala belum tentu berkolerasi dengan karya atau tulisan yang dihasilkannya, melainkan minat dan keinginan dalam menulis itu menjadikan beberapa peserta mempunyai pengalaman dalam mempublikasikan pengalaman mengajar ke dalam karya ilmiah baik jurnal maupun prosiding. Topik karya ilmiah dominan berhubungan dengan kegiatan pembelajaran di kealas, sedangkan aspek kebahasaan dan kesastraan masih sangat terbatas.

3. Teknik dalam Tahap Perumusan Tujuan dan Diskusi Kelompok

Setelah disajikan beberapa topik yang bisa dilakukan dalam penulisan karya ilmiah, peserta diminta membentuk kelompok untuk mendiskusikan kemungkinan topik-topik seperti apa yang bisa dikembangkan dalam penulisan karya ilmiah. Setelah peserta memeroleh topik penelitian, peserta diminta mencari sumber informasi penelitian terdahulu yang pernah dilakukan di setiap topik minimal lima artikel penelitian. Walupun mereka berkelompok, namun peserta tetap diminta untuk melaporkan tugasnya dalam bentuk merivew artikej jurnal penelitian yang mereka baca secara mandiri. Hal itu dilakukan dengan harapan peserta mampu merumuskan topik penelitian yang tepat dan akurat yang berbasis penelitian.

4. Teknik pada Tahap Penyusunan Program

Setelah peserta menemukan topik permasalahn penelitian, peserta merancang karya ilmiah dalam bentuk kerangka. Kerangka itu disesuaikan dengan retorika penulisan karya ilmiah baik pada pendahuluan maupun pada bagian abstraknya. Peserta diberikan kesempatan selama lebih kurang 90 menit untuk merumuskan bagian pendahuluan dalam karya ilmiah.

5. Teknik yang Dapat Dipergunakan dalam Proses Pelatihan: simulasi, studi kasus, cerita pemula diskusi (discussion starter story), pemecahan masalah kritis, dan forum.

Setelah masing-masing peserta menulis bagian pendahuluan artikel jurnal penelitian itu, perwakilan masing-masing kelompok mempresentasikan tulisan yang telah mereka tulis, sedangkan kelompok lain memberikan masukan, kritik, atau pertanyaan demi kesempurnaan tulisannya berdasarkan materi yang sudah diberikan sebelumnya. Hal ini dilakukan sampai semua kelompok dapat mempresentasikan hasil tulisannya dengan baik. Setiap peserta yang sudah presentasi dan tanggapan dari semua peserta, pelatih memberikan komentar dari 
beberapa catatan yang sudah disimak atau diperhatikal dari awal. Hal umum terjadi pada bagian pendahuluan ini masih kurangnya argumen penulis pada move menjastifikasi kegiatan pepenlitian dan memperkenalkan kegiatan penelitian. Hal dominan yang terdapat dalam move bagian pendahuluan ini masih berkisar pada menyiapkan pengetahuan pembaca dan memperkenalkan bidang penelitian.

6. Teknik yang Dapat Dipergunakan dalam Penilaian Proses Pelatihan, Hasil dan Pengaruh Kegiatan: respon terinci, dan pengajuan pendapat tertulis.

Teknik yang keenam ini dalam pelaksanaannya sudah sekaligus dilakukan pada teknik kelima, namun penilaian di sini dilakukan setalah semua kelompok mempresntasikan hasil tulisannya dan saat kegiatan pelatihan dilakukan. Penilaian disini berhubungan dengan evaluasi terhadap tulisan yang dihasilkan secara menyeluruh dan respon peserta terhadap pelatihan yang telah dilakukan mulai dari awal kegiatan sampai selesai pelatihan dilakukan. Berdasarkan respon peserta mengemukakan bahwa kegiatan seperti ini perlu dilakukan dan ditindaklajuti dalam bentuk pembimbingan agar tulisan yang dihasilkan mampu untuk dipublikasikan.

\section{HASIL DAN LUARAN}

Analisis teks berdasarkan genre dilakukan sebelum pelatihan dan sesudah pelatihan yang ditulis oleh para peserta pelatihan. Distribusi bergerak dalam abstrak RA ditampilkan dalam tabel berikut.

Tabel 1. Distribusi Move dalam Abstrak

\begin{tabular}{clcc}
\hline Move & \multicolumn{1}{c}{ Deskripsi } & $\begin{array}{c}\text { Sebelum } \\
\text { Pelatihan }\end{array}$ & $\begin{array}{c}\text { Sesudah } \\
\text { Pelatihan }\end{array}$ \\
\hline Move-1 & Background/introduction/situation & - & 6 \\
\hline Move-2 & The purpose of the research & 9 & 9 \\
\hline Move-3 & $\begin{array}{l}\text { Methodology/materials/subject or the } \\
\text { procedure how research is conducted }\end{array}$ & 9 & 9 \\
\hline Move-4 & Results/findings & 9 & 9 \\
\hline Move-5 & Conclusion/significance & - & 6 \\
\hline
\end{tabular}

Tabel 1 menunjukkan bahwa ada peningkatan yang signifikan dalam kualitas abstrak sebelum pelatihan dan sesudah pelatihan dalam hal jumlah move yang ditemukan dalam abstrak. Jumlah abstrak yang tidak memiliki move telah sepenuhnya memiliki move dari 9 abstrak hampir rata-rata sudah memiliki move abstrak yang lengkap. 
Tabel 2. Distribusi Move dalam Bagian Pendahuluan

\begin{tabular}{clcc}
\hline Move & \multicolumn{1}{c}{ Description } & $\begin{array}{c}\text { Sebelum } \\
\text { Pelatihan }\end{array}$ & $\begin{array}{c}\text { Sesudah } \\
\text { Pelatihan }\end{array}$ \\
\hline Move-1 & Establishing a territory & & \\
\hline Step-A & Claiming centrality & $\mathbf{4}$ & $\mathbf{8}$ \\
\hline Step-B & Making topic generalization & 8 & 9 \\
\hline Step-C & Reviewing items from previous research & $\mathbf{6}$ & $\mathbf{9}$ \\
\hline Move-2 & Establishing a niche & & \\
\hline Step-A & Counter claiming & 3 & 4 \\
\hline Step-B & Indicating a gap & $\mathbf{5}$ & $\mathbf{9}$ \\
\hline Step-C & Question-raising & - & - \\
\hline Step-D & Continuing a tradition & - & - \\
\hline Move-3 & Occupying a niche & 3 & 9 \\
\hline Step-A & Outlining purposes & 5 & 7 \\
\hline Step-B & Announcing present research & - & 2 \\
\hline Step-C & Announcing principle findings & - & - \\
\hline Step-D & Indicating research article structure & &
\end{tabular}

Berdasarkan Tabel 2 di atas artikel peserta meningkat secara signifikan dalam penggunaan retorika penting dalam pendahuluan seperti, menggunakan Move-1-Step-A (claiming centrality), Move-1-Step-C (reviewing items from previous research), Move2-Step-B (indicating a gap) dan Move3-Step-A (outlining purposes).

Berdasarkan hasil pelatihan yang telah diuraikan di atas, umumnya peserta tidak mengikuti gaya retorika yang semestinya baik dari gaya penulisan orang Indonesia maupun yang berlaku dalam bahasa Inggris. Hal itu sesuai juga dengan Adnan (2009). Adnan dari korpus data penelitiannya yang diambil dari tiga jurnal yang berbeda dalam disiplin ilmu humaniora menemukan bahwa para penulis Indonesia tidak mengikuti gaya retorika yang umum berlaku dalam bahasa Inggris yang ditulis oleh penulis Inggris terutama mengacu kepada model create a research space atau CARS dari Swales (1990). Namun, Adnan menyarankan agar penelitian tentang gaya retorika AJP berbahasa Inggris yang ditulis dalam bahasa Inggris oleh penulis Indonesia perlu dilakukan lebih banyak lagi untuk mengkonfirmasi temuannya terutama dengan menggunakan sumber data AJP berbahasa Inggris dalam bidang-bidang ilmu selain humaniora.

Penelitian tentang gaya retorika pendahuluan AJP berbahasa Inggris yang ditulis oleh penulis Indonesia dilakukan oleh Safnil (2013). Data penelitian Safnil diambil dari 30 AJP yang berasal dari tiga jurnal internasional yang berbeda yang terbit di Indonesia (ITB Journal of Engineering Science, Acta Medica Indonesia, dan ITB Journal of Science). Temuan penelitian Safnil memperkuat temuan penelitian terdahulu (Mirahayuni, 2002 dan Adnan, 2009) dimana gaya retorika pendahuluan AJP berbahasa Inggris yang ditulis oleh penulis Indonesia berbeda dengan gaya retorika pendahuluan 
AJP yang ditulis oleh penulis Inggris. Salah satu perbedaanya menurut Safnil adalah pada Move-2 (niche establishment) atau cara penulis mendukung pentingnya kegiatan penelitian yang telah dilakukan hanya 15 (50\%) dari penulis Indonesia yang menggunakan Move yang sama dengan cara yang dilakukan oleh penulis Inggris seperti dalam model CARS. Perbedaan ke dua adalah diantara 15 penulis AJP Indonesia yang menggunakan Move-2 (niche establishment) dalam usaha meyakinkan pembaca akan pentingnya penelitian mereka, tidak satupun yang menggunakan Step-1 (counter claiming) atau mendasarkan pentingnya kegiatan penelitian atas dasar evaluasi atau kritik terhadap penelitian terdahulu.

Safnil (2013) juga menemukan persamaan antara gaya retorika pendahuluan AJP berbahasa Inggris yang ditulis oleh penulis Indonesia dan yang ditulis oleh penulis internasional. Semua bagian AJP berbahasa Inggris oleh penulis Indonesia memiliki Move-1 (territory establishment) dan Move-3 (niche occupying) dan hampir semua AJP tersebut menggunakan penanda contrastive discourse seperti while, however dan but dan lexical negation seperti very limited, has not been dan not yet untuk membantu pembaca dalam membaca artikel tersebut. Persamaan ini mungkin disebabkan karena penulis Indonesia yang menulis AJP dalam bahasa Inggris ini banyak membaca AJP berbahasa Inggris sebagai referensi baik dalam menulis proposal maupun dalam laporan penelitian mereka.

Penelitian terakhir tentang pola retorika pendahuluan AJP berbahasa Indonesia dalam bidang ilmu-ilmu sosial dan humaniora dilakukan oleh Arsyad dan Wardana (2014) dan Arsyad dan Arono (2015) dalam bidang sains, teknologi dan kedokteran dan kesehatan. Mereka meneliti 400 pendahuluan AJP Indonesia dalam berbagai bidang ilmu dengan menggunakan pola PJP sebagai model. Hasil penelitian mereka mendukung temuan penelitian terdahulu dimana gaya retorika pendahuluan AJP Indonesia dapat diungkap lebih baik dengan menggunakan model PJP dari pada model CARS. Temuan ini menegaskan bahwa gaya retorika AJP Indonesia berbeda dengan gaya retorika pendahuluan AJP berbahasa Inggris seperti dalam model CARS.

Berdasarkan beberapa penelitian dan pengabdian masyarakat yang telah dilakukan di atas menunjukkan bahwa pelatihan dapat memberikan peningkatan kemampuan menulis karya ilmiah bagi peserta pelatihan, namun masih kurang terlihat mengkaji bagaimana pengembangan model pelatihan tersebut dalam pelaksanaannya sampai pada evaluasinya atau pada draf publikasi dalam bentuk prosiding atau jurnal karena dari 32 peserta hanya mampu mempublikasikan tulisannya dalam bentuk prosiding berjumlah 9 peserta atau dalam prosentase sebesar $28 \%$.

Somarya (2009) melakukan pengabdian masyarakat terhadap Pelatihan dan Pendampingan Pembuatan Karya Tulis Ilmiah Bagi Guru Sekolah Dasar di Wilayah Priangan Barat. Hasil kegiatan ini, yaitu tingkat partisipasi kehadiran peserta pada pelatihan dan pendampingan pertama sangat antusias, sedangkan pada pendampingan berikutnya relatif berkurang, tingkat pemahaman peserta pada waktu pelatihan adanya 
pemahaman yang cukup, sedangkan pada waktu pendampingan para peserta masih dapat dikatakan relatif memahami, dan tanggapan peserta berdasarkan wawancara pada 5 orang guru menunjukkan bahwa pelatihan dan pendampingan seperti ini perlu dilaksanakan secara berkelanjutan, hanya saja hasil pembuatan karya ilmiah masih sedang berjalan. Implikasi dari kegiatan ini dapat meningkatkan mutu pembelajaran, menulis analitik, dan bekal bagi persyaratan kenaikan pangkat serta pengajuan sertifikasi guru.

Ismiati, dkk (2010) melakukan pelatihan karya tulis ilmiah bagi kepala sekolah mengah pertama di Kabupaten Bantul secara umum semua peserta mengikuti kegiatan dengan motivasi tinggi dan sungguh-sungguh. Hal ini tampak pada kehadiran mereka secara rutin selama tiga hari dan mengikuti setiap sesi dengan penuh perhatian dan antusiasme yang tinggi. Pertanyaan-pertanyaan mereka lontarkan pada saat dibuka sesi diskusi. Hal-hal yang kurang jelas mereka tanyakan sampai diperoleh pemahaman. Hari pertama kegiatan pelatihan, peserta mengikuti dengan seksama. Mereka merasa mendapat pengetahuan baru yang selama ini belum mereka ketahui, para peserta menjadi lebih paham tentang konsep dan aspek-aspek karya tulis ilmiah dan cara penulisannya secara terstandar. Hal ini terbukti dengan hasil karya ilmiah yang mereka bawa pada pertemuan kedua yang sebagian besar sudah memenuhi kriteria sebagai karya ilmiah yang baik. Hari kedua kegiatan berupa Pembimbingan/Konsultasi Penulisan KTI. Peserta sangat antusias memanfaatkan kesempatan ini untuk berkonsultasi, bertanya, dan memperbaiki karya ilmiah yang telah ditulisnya. Pada hari ke tiga, para peserta telah membawa karya tulis ilmiah masing-masing yang telah diperbaiki berdasarkan saran dan masukan yang diberikan oleh tim pengabdi sebelumnya. Ternyata dari semua karya ilmiah yang dikumpulkan dapat dinilai sesuai kriteria karya tulis ilmiah.

Berdasarkan beberapa penelitian dan pengabdian masyarakat yang telah dilakukan di atas menunjukkan bahwa pelatihan dapat memberikan peningkatan kemampuan menulis karya ilmiah bagi peserta pelatihan, namun masih kurang terlihat mengkaji bagaimana pengembangan model pelatihan tersebut dalam pelaksanaannya sampai pada evaluasinya atau pada draf publikasi dalam bentuk prosiding atau jurnal. Hal itulah yang membedakan peneliti dalam menerapkan model pelatihan karya tulis ilmiah dengan pelatihan yang terdahulu.

Adapun faktor pendukung dalam pelatihan ini, yaitu; (1) Pihak sekolah dan perguruan tinggi sangat merespon kegiatan MGMP yang dilaksanakan di STKIP PGRI Lubuk Linggau jika memungkinkan kegiatan ini dapat dilanjutkan serta berkesinambungan. Hal itu memungkinkan karena kampus ini ditunjuk sebagai perguruan tinggu swasta percontohan bidang keguruan sehingga merlukan aktivitas yang menunjang keprofesionalan guru kgususnya di Lubuk Linggau, (2) Ketua MGMP bahasa Inggris dan bahsa Indonesia juga ketua prodinya menyambut baik pelatihan ini karena penulisan artikel ilmiah untuk dipublikasikan merupakan masalah yang dihadapi 
semua peserta MGMP maupun dosen yang merupakan guru bahasa Inggris dan bahasa Indonesia dari berbagai sekolah menengah pertama di Lubuk Linggau, (3) Peserta memberikan respon positif terhadap kegiatan ini dengan mengirimkan hasil penelitiannya kepada peneliti, (4) Semua peserta telah mendapatkan pelatihan penulisan artikel jurnal penelitian bagian abstrak dan pendahuluan yang akan menjadi dasar bagi peserta untuk membuat penelitian untuk kemudian ditulis dalam bentuk laporan hasil penelitian lalu dipublikasikan dalam bentuk artikel ilmiah, (5) Kebutuhan penulisan karya ilmiah yang dipublikasikan sangat diperlukan peserta untuk penilaian yang berhubungan dengan tunjangan sertifikasi.

Adpun faktor penghambat dalam pelatihan ini, yaitu (1) Kemampuan guru menulis hasil penelitian dalam bentuk laporan masih terbatas, walaupun telah mendapatkan pelatihan sehingga menghambat guru untuk mempublikasikan hasil penelitian yang dilakukan, (2) Kesibukan peserta di sekolah dan di rumah membuat mereka, yang sebagian besar adalah ibu-ibu, kesulitan meluangkan waktu untuk menulis apalagi menjelang kenaikan kelas, (3) Peserta masih bingung dan ragu mengenai hasil penelitian seperti apa yang bisa dipublikasikan, (4) Wadah seperti jurnal di Lubuk Linggau masih terbatas serta kegiatan pelatihan seperti ini masih sangat jarang, dan (5) Penghargaan dari daerah terhadap guru atau dari pimpinan masih sangat terbatas.

Pengabdian ini dilaksanakan pada hari Rabu, tanggal 19 September 2019 dengan jumlah peserta yang hadir sebanyak 32 orang. Dengan telah dilaksanakan kegiatan pengabdian ini, peserta termotivasi dan terbuka wawasannya untuk meningkatkan profesionalitas dengan membuat artikel ilmiah untuk dipublikasikan. Mereka baru menyadari bahwa mempublikasikan karya ilmiah mereka sangat bermanfaat dan membantu mereka memenuhi kewajiban mereka sebagai guru dan dosen yang tersertifikasi dan layak disebut sebagai guru profesional. Menulis hasil penelitian memang membutuhkan waktu dan pikiran yang tidak sedikit sehingga diperlukan juga perjuangan dan pengorbanan peserta untuk membuatnya kemudian dijadikan artikel ilmiah untuk dipublikasikan.

Metode yang digunakan dalam mengevaluasi keberhasilan kegiatan ini digunakan ada dua jenis, yaitu evaluasi dampak dan evaluasi pelaksanaan program. Jika pelaksanaan kegiatan sesuai dengan model induktif partisipasif, kegiatan telah berjalan sesuai dengan tujuan dan dampak yang diharapkan dari kegiatan ini adalah dampak positif berupa motivasi yang tinggi pada diri peserta untuk mempublikasikan semua hasil penelitian yang telah dilakukan dalam bentuk jurnal atau prosiding. Pada tahap awal kegiatan ini, diberikan suatu analisis kebutuhan dan kondisi saat ini dalam kebiasaan menulis yang dilakukan oleh bapak dan ibu guru. Dari hasil analisisi kebutuan dan kekinian dalam menulis karya ilmiah masih sangat terbatas. Oleh karena itu, diperlukan materi-materi yang berkaitan dengan artikel jurnal. Peserta menganggap bahwa menulis. Adapun beberapa catatan dikemukakan bahwa menulis itu sebagai sesuatu yang sulit, menulis dikerjakan sebatas menyelesaikan pendidikan, kebiasaan 
menulis masih jarang, pada bagian merumuskan masalah peserta kesulitannya, kebiasaan membaca masih kadang-kadang, lingkungan kurang mendukung dalam aktivya ilmiah yang baik.

Penyuluhan dan pelatihan ini dilaksanakan dalam tiga sesi, sesi pertama penyampaian materi mengenai "Penulisan bagian Asbtrak Artikel Hasil Penelitian" dan sesi kedua "Penulisan bagian Pendahuluan Artikel Hasil". Pada sesi ini banyak keluhan dan ketidaktahuan dari peserta mengenai apa yang harus mereka lakukan untuk memulai dan melakukan penelitian. Bahkan, ada yang hanya sekali melakukan penelitian dan melaporkannya dalam bentuk skripsi pada tahun 90-an. Sesi kedua adalah simulasi membuat contoh judul penelitian dan formatnya oleh peserta berdasarkan fenomena atau masalah yang terjadi di kelas para peserta. Pada sesi diskusi terlihat antusias peserta untuk membuat penelitian karena mempublikasikan karya ilmiah merupakan pekerjaan besar dan memiliki tantangan tersendiri bagi peserta. Pada sesi ketiga, peserta lebih antusias dari segi pengeditan terhadap tulisan. Dengan adanya kegiatan saling mengoreksi akan memungkinkan tulisan kita akan semakin baik.

Setelah melakukan bimbingan kepada peserta yang telah mengirimkan karya ilmiah melalui email, untuk memastikan bahwa artikel tesebut benar-benar layak dipublikasikan. Berdasarkan hasil bimbingan, hanya 9 artikel yang mampu mengikutkan dalam bentuk publikasinya dalam seminar nasional melalui prosiding Seminar Nasional mengenai Pengembangan Bahan Ajar. Secara umum, semua peserta antusias mengikuti pelatihan yang terlihat dari keaktifan mereka bertanya. Pertanyaan-pertanyaan mereka lontarkan berkaitan dengan bagaimana cara membuat penelitian, fenomena apa yang bisa dijadikan penelitian, bagaimana membuat artikel ilmiah, dan bagaimana cara memasukkan artikel ke dalam jurnal atau prosiding untuk dipublikasikan. Hal-hal tersebut mereka tanyakan sampai paham.

Setelah pelatihan dilakukan, selanjutnya peserta dan peneliti berhubungan melalui email. Ada tiga hasil penelitian yang dikirimkan oleh peserta untuk dibimbing agar bisa dipublikasikan. Peserta yang belum mengirimkan hasil penelitian terkendala menulis hasil penelitian yang mereka lakukan sehingga belum bisa mengirimkan hasil penelitian mereka dan mengubahnya menjadi artikel ilmiah. Tanggal 3 November 2018 Jurusan Pendidikan Bahasa dan Seni mengadakan Seminar Nasional sehingga peneliti membantu peserta memasukkan artikel mereka agar diterima sebagai artikel yang akan dipresentasikan saat seminar. Mereka mengharapkan diadakan lagi pelatihan serupa dan bimbingan dari pelatih untuk membuat artikel-artikel ilmiah selanjutnya, namun mereka lebih mengharapkan bimbingan dalam menulis artikel jurnal penelitian.

Kegiatan pengabdian masyarakat yang telah dilaksanakan melalui model Penyuluhan model induktif partisipatif mampu meningkatan kualitas mutu tulisan guru dalam menulis karya tulis ilmiah. Tahap yang dilakukan dalam penerapan model ini adalah, (1) Teknik dalam Tahap Pembinaan Keakraban. Teknik ini digunakan pelatih dalam mencairkan suasana dan suasana lebih akrab. Hal itu dilakukan pelatih dengan 
memperkenalkan diri begitu juga dengan pesertanya. Selain itu, pelatih juga memberikan informasi dan gambaran umum berbagai permasalalahn dalam penulisan karya ilmiah, serta pengalaman-pengalaman yang baik suka maupun duka dalam menulis karya ilmiah juga mempublikasikan tulisan itu. Saat itu juga beberapa peserta pelatihan diminta menceritakan pengalamannya. Umumnya peserta mengalami kesulitan dalam menuangkan ide dan mempublikasikan tulisan karya ilmiahnya dalam bentuk jurnal atau prosiding. Hal itu karena terbatasnya wadah publikasi dan kegiatan seminar yang dilakukan di daerahnya, (2) Teknik yang Dipergunakan pada Tahap Identifikasi. Teknik ini digunakan oleh pelatih dalam menggali informasi berbagai permasalahan peserta terhadap pengalaman yang telah dilakukan dalam penulisan karya ilmiah. Pengalaman penulis peserta tidak terlepas dari pengalaman peserta dalam melakukan aktivitas belajar dan mengajar di kelas. Lamanya pengalaman kadangkala belum tentu berkolerasi dengan karya atau tulisan yang dihasilkannya, melainkan minat dan keinginan dalam menulis itu menjadikan beberapa peserta mempunyai pengalaman dalam mempublikasikan pengalaman mengajar ke dalam karya ilmiah baik jurnal maupun prosiding. Topik karya ilmiah dominan berhubungan dengan kegiatan pembelajaran di kealas, sedangkan aspek kebahasaan dan kesastraan masih sangat terbatas, (3) Teknik dalam Tahap Perumusan Tujuan dan Diskusi Kelompok. Setelah disajikan beberapa topik yang bisa dilakukan dalam penulisan karya ilmiah, peserta diminta membentuk kelompok untuk mendiskusikan kemungkinan topik-topik seperti apa yang bisa dikembangkan dalam penulisan karya ilmiah. Setelah peserta memeroleh topik penelitian, peserta diminta mencari sumber informasi penelitian terdahulu yang pernah dilakukan di setiap topik minimal lima artikel penelitian. Walupun mereka berkelompok, namun peserta tetap diminta untuk melaporkan tugasnya dalam bentuk merivew artikej jurnal penelitian yang mereka baca secara mandiri. Hal itu dilakukan dengan harapan peserta mampu merumuskan topik penelitian yang tepat dan akurat yang berbasis penelitian, (4) Teknik pada Tahap Penyusunan Program. Setelah peserta menemukan topik permasalahn penelitian, peserta merancang karya ilmiah dalam bentuk kerangka. Kerangka itu disesuaikan dengan retorika penulisan karya ilmiah baik pada pendahuluan maupun pada bagian abstraknya. Peserta diberikan kesempatan selama lebih kurang 90 menit untuk merumuskan bagian pendahuluan dalam karya ilmiah, (5) Teknik yang Dapat Dipergunakan dalam Proses Pelatihan: simulasi, studi kasus, cerita pemula diskusi (discussion starter story), pemecahan masalah kritis, dan forum. Setelah masing-masing peserta menulis bagian pendahuluan artikel jurnal penelitian itu, perwakilan masing-masing kelompok mempresentasikan tulisan yang telah mereka tulis, sedangkan kelompok lain memberikan masukan, kritik, atau pertanyaan demi kesempurnaan tulisannya berdasarkan materi yang sudah diberikan sebelumnya. Hal ini dilakukan sampai semua kelompok dapat mempresentasikan hasil tulisannya dengan baik. Setiap peserta yang sudah presentasi dan tanggapan dari semua peserta, pelatih memberikan komentar dari beberapa catatan yang sudah disimak atau 
diperhatikal dari awal. Hal umum terjadi pada bagian pendahuluan ini masih kurangnya argumen penulis pada move menjastifikasi kegiatan pepenlitian dan memperkenalkan kegiatan penelitian. Hal dominan yang terdapat dalam move bagian pendahuluan ini masih berkisar pada menyiapkan pengetahuan pembaca dan memperkenalkan bidang penelitian, (6) Teknik yang Dapat Dipergunakan dalam Penilaian Proses Pelatihan, Hasil dan Pengaruh Kegiatan: respon terinci, dan pengajuan pendapat tertulis. Teknik yang keenam ini dalam pelaksanaannya sudah sekaligus dilakukan pada teknik kelima, namun penilaian di sini dilakukan setalah semua kelompok mempresntasikan hasil tulisannya dan saat kegiatan pelatihan dilakukan. Penilaian disini berhubungan dengan evaluasi terhadap tulisan yang dihasilkan secara menyeluruh dan respon peserta terhadap pelatihan yang telah dilakukan mulai dari awal kegiatan sampai selesai pelatihan dilakukan. Berdasarkan respon peserta mengemukakan bahwa kegiatan seperti ini perlu dilakukan dan ditindaklajuti dalam bentuk pembimbingan agar tulisan yang dihasilkan mampu untuk dipublikasikan. Kegiatan ini berhasil membantu bebera orang peserta mempublikasikan karya ilmiahnya dalam prosiding hasil penelitian yang layak publish di seminar nasional dalam bentuk prosiding.

\section{KESIMPULAN}

Berdasarkan hasil pelaksanaan dan manfaat yang diterima oleh para guru yang menjadi peserta kegiatan ini, pengabdian ini lebih baik jika kegiatan ini terus dilanjutkan karena akan sangat membantu guru yang kenaikan pangkat dan kariernya untuk mempublikasikan karya ilmiahnya. Selian itu, pembimbingan secara kontinu baik online maupun tatap muka perlu ditindak lanjuti dan secara intensif agar peblikasi bagi guru dan dosen dapat meningkat.

\section{DAFTAR PUSTAKA}

Amirin, T. M. 2001. Pokok-Pokok Teori Sistem. Jakarta: PT Raja Grafindo Persada. Arsyad, S. 2014. Menulis Artikel Jurnal Internasional dengan Gaya Retorika Bahasa Inggris. Jakarta: Halaman Moeka.

Bappenas. 2014. Daftar 183 Daerah Tertinggal. (http://kawasan.bappenas.go.id/) diakses pada tanggal 25 April 2014.

Bappenas. 2014. Daftar Kawasan Perbatasan 2010-2014. (http://kawasan.bappenas.go.id/images/RKP2013/TABEL\%20LOK-PRI-20122014-NETT.pdf) diakses pada tanggal; 25 April 2014.

BP-PLSP Reg III. 2004. Model Pelatihan Pamong Belajar Ahli Berbasi Kompetensi. Jawa Tengah: Depdiknas. 
Harian Rakyat Bengkulu. 2015. Nasib 275 Guru Daerah Terpencil, Menggantung. (http://harianrakyatbengkulu.com/ver3/2015/03/09/nasib-275-guru-daerahterpencil-menggantung/) diakses pada tanggal 25 April 2015.

Ismaniati, C., dkk. 2010. Pelatihan Penulisan Karya Ilmiah bagi Kepala SMPN di Lingkungan Diknas Pendidikan Dasar Se-Kabupaten Bantul. Yogyakarta: UNY.

Kamil, M. 2003. Model-model Pelatihan. Bandung: UPI.

KPDT. 2011. 183 Kabupaten Tertinggal di Indonesia.

(http://www.kemenegpdt.go.id/hal/300027/183-kab-daerah-tertinggal) diakses pada tanggal 25 April 2014.

Laird, D. 1985. Approaches to Training and Development. Addison-Wesley: Publishing Company.

Leutuan, Rasyid.,A. H. 2010. Profesi Guru dan Permasalahannya Profesional Guru dan Permasalahannya.

(http://harunalrasyidleutuan.wordpress.com/2010/01/22/frofesi-guru-danpermasalahannya-profesional-guru-dan-permasalahannya/) diakses pada tanggal 20 April 2014.

Nadler, L. 1982. Designing Training Program: The Critical Events Model. Canada: Addison Wesley.

Permendiknas. 2007. Pemenpan Nomor 84/1993 tentang Kepangkatan.

Rossett, A. \& Arwady, W., Joseph. 1987. Training Needs Assesment. Educational Technology Publications Englewood Cliffs: New Jersey.

Safnil dan Arono. 2016. Sukses Menulis Pendahuluan Artikel Jurnal Internasional. Jakarta: Halaman Moeka.

Somarya, D. 2009. Pelatihan dan Pendampingan Pembuatan Karya Tulis Ilmiah bagi Guru Sekolah Dasar di Wilayah Priangan Barat. Jakarta: DIKTI.

Sudjana, D. 1993. Metoda danTteknik Pembelajaran Partisipatif. Bandung: Nusantara Press.

Supriadi, D. 1999. Mengangkat Citra Guru dan Martabat Gur. Yoyakarta: Adicita Karya Nusa.

Trianto. 2009. Mendesain Pembelajaran Inovatif Progresif. Jakarta: Kencana Prenada Media Group.

Undang-Undang Republik Indonesia. 2005. Tentang guru dan dosen. 